\title{
Cold Extrusion and Cold Drawing of Polymeric Rod: The Influence on Subsequent Tensile and Compressive Mechanical Properties
}

\author{
CHUL S. LEE and ROBERT M. CADDELL \\ Department of Mechanical Engineering, University of Michigan, Ann Arbor, Mich. (U.S.A.) \\ and
}

GREGORY S. Y. YEH

Departments of Materials and Metallurgical Engineering, and Chemical Engineering, University of Michigan, Ann Arbor, Mich. (U.S.A.)

(Received March 17, 1972)

\section{Summary ${ }^{\star}$}

Nylon 6-6, polycarbonate and high density polyethylene were extruded and drawn through a $40 \%$ reduction die in one pass at room temperature. Certain mechanical properties of the extrudate were measured by subsequent tension and compression tests. For both forming processes and for all three polymers, the tensile true stress-true strain curve is raised compared with the behavior of the original material while the comparable compressive curve is lowered. It was also found that the onset of tensile instability was extended to larger tensile strains when these polymers were first cold worked by extruding or drawing. The elastic modulus was increased when PC was extruded or drawn while this property exhibited a decrease, due to cold working, for both other polymers.

All three materials exhibited pronounced directional effects when subjected to compressive loading both parallel to and perpendicular to the longitudinal axis of the extrudate. In a qualitative manner this seems to correlate with greater chain alignment brought about by the forced flow through the die throat.

Exploratory temperature measurements indicate that a maximum rise of $20 \mathrm{deg} F$ resulted for this severe reduction of area; this would not cause the glass transition temperature of the PC and Nylon to be exceeded.

\section{INTRODUCTION}

It is well known that the macroscopic mechanical properties of ductile metals can be altered signifi-

* For French and German translations of the Summary, see p. 242. cantly when those metals are cold formed by numerous processes. Because of the limited number of studies reported in the published literature, it is less well established just how cold forming affects those properties of polymeric solids. Cold rolling and extrusion have been studied to some extent ${ }^{1-5}$.

In comparing findings from these studies, some unexplained contradictions seem to exist. These may be due to how the measured properties are defined (e.g. "yield stress" appears to be measured in several arbitrary ways). Again, the difference in loading mode (e.g. rolling versus extrusion) may produce dissimilar variations in structure with the consequence that property changes differ. Additionally, $T_{\mathrm{g}}$ and degree of initial crystallinity of the numerous polymers, used in the aforementioned references, vary widely; this may explain that the effects of "cold forming" at room temperature are more pronounced with some polymers than with others.

Several points of interest were pursued in the study that produced the findings in this paper. It was intended to evaluate the possible influence of loading mode (i.e. the applied state of stress) on resultant properties. This was accomplished by extruding (pushing) and drawing (pulling) round rod through the same die setup thereby producing rods of smaller diameter. Property measurements of these smaller rods were obtained. To scan a few combinations of materials having different degrees of crystallinity and values of $T_{\mathrm{g}}$, polycarbonate (PC), Nylon 6-6 (N) and high density polyethylene (PE) served as test materials. As this was an exploratory study whose major emphasis was on the potential process effects and not on a variety of controlled structures, a deliberate decision was 
made to use commercially supplied materials. It is hoped that these findings will point to ideas not discussed previously, and may indicate that a great amount of systematic effort is required before the effect of cold forming on the macroscopic properties of polymers is really well understood.

\section{PROCEDURE}

Single rods of each polymer (PC, N and PE), initially six feet long by $\frac{3}{4}$ inch diameter, were obtained as regular commercial materials from Cadillac Plastics. All subsequent test specimens were made from these rods in the hope of minimizing any processing variations for each specific material.

Specimens to be extruded were made by turning down the original diameter to 0.675 inch and facing off cylindrical sections to about three-inch lengths. They were extruded as indicated in the schematic illustration of Fig. 1a to produce a cylindrical rod of an unrelaxed diameter of 0.524 inch and a useful length of about four inches. This "nominal" reduction of area was $40.5 \%$ and was completed in a single pass at room temperature.

For the drawing operation, test specimens had a working section identical with those used for extrusion. In addition, a reduced section was machined to clear the opening of the die outlet and provided adequate length for attachment to the moving power source. The schematic illustration of Fig. 1b should clarify these comments.

Power was provided by a Riehle Testing Machine which produced an extrusion or drawing speed of $\frac{1}{3}$ inch per minute. Using suggested equations ${ }^{6}$, this caused a strain rate of the order of $10^{-3}$ per second. All test specimens and contact surfaces of the

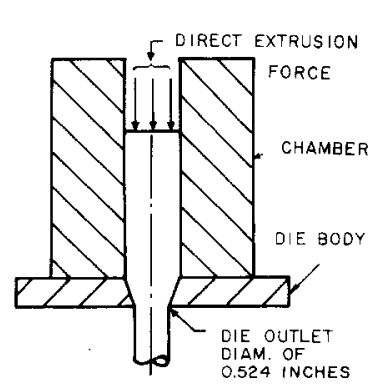

(A) EXTRUSION

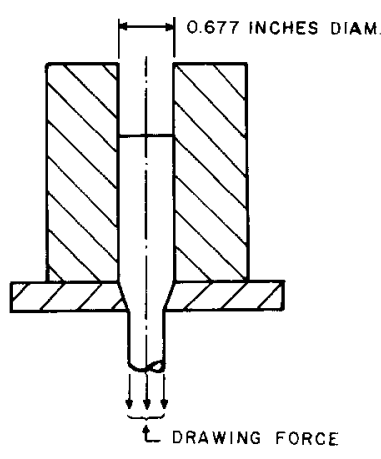

(B). DRAWING
Fig. 1. Schematic illustration of rod extruding and drawing.

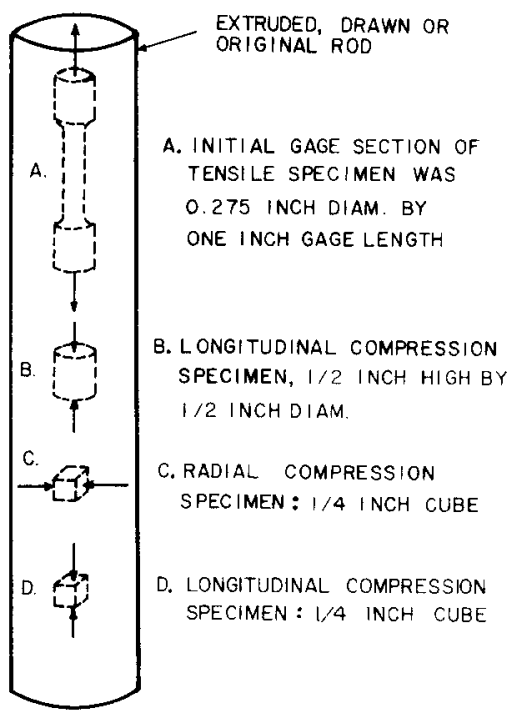

Fig. 2. Sketch of the location and subsequent loading directions using tensile and compression specimens made from the original, extruded and drawn rods.

die setup were lubricated with petroleum jelly. Each test produced a cold worked section or rod of about four inches in length and initial diameter of 0.524 inch. Diametral measurements were made over a 48 hour period to verify that "full" relaxation resulted. This time period was quite adequate for all three materials.

Specimens for subsequent tensile and compressive tests were made from each cold worked rod. Figure 2 illustrates the specimen orientation. Note that because of size limitations, tensile tests were conducted only by loading parallel to the longitudinal axis of the drawn or extruded rods. Pertinent dimensions of these specimens are noted on Fig. 2 which is not drawn to scale. The arrows portray the subsequent loading directions and the specimens are coded $A-D$ for future reference.

All tensile specimens (type A in Fig. 2 plus duplicates from the original rods) were tested on a $500 \mathrm{~kg}$ Instron machine; a standard strain gage extensometer was used to drive the strip chart recorder. With the onset of necking or tensile instability, the extensometer was removed from the specimen. Further measurements of area changes were made using point micrometers; these were always taken in the smallest apparent cross section and provided strain information after this non-uniform deformation had commenced. Loads that coincided with these specific area measurements were also recorded. In effect, these values of instantaneous load and area 
were used to compute true stress-true strain behavior well beyond the start of necking.

The larger compression specimens (type B in Fig. 2 plus duplicates from the original rods) were loaded on a 10,000 pound Instron machine; there the strip chart was driven at a fixed speed using drive gears. Changes in specimen diameter were measured with vernier calipers. To check dimensional changes, the crosshead speed and chart speed were coordinated to enable one to compute the apparent change in specimen height. This provided a reasonable check of the diameter measurements and a number of load-diameter combinations were recorded to provide the raw data that led to true stress-true strain compression plots. As soon as any non-uniform change in specimen geometry was apparent, that test was ended. Barreling was most typical of non-uniform deformation.

With the smaller compression cubes (types $\mathrm{C}$ and $\mathrm{D}$ in Fig. 2 plus duplicates for the original rods), tests were conducted on the smaller Instron machine. As these tests were intended to indicate only major differences in loading direction, load-displacement data were obtained and converted to nominal engineering stress-strain curves. It was felt that such comparative results would portray any meaningful differences; this negated the need of making physical size measurements on these small specimens as they deformed.

All tests involved an Instron crosshead speed of 0.02 inch per minute and petroleum jelly was used as the interface lubricant for all compression tests. Again, strain rates were of the order of $10^{-3}$ per second.

Exploratory tests were performed to provide some quantitative data regarding the gross temperature rise due to these forming processes. Since the extrusion process was likely to be the more severe, it was sensible to restrict these limited studies to that deformation mode. Copper-constantan thermocouples were embedded into small holes that had been drilled into a typical extrusion specimen; the initial fit could be classed as "snug". The output of these thermocouples was fed to an $\mathrm{X}-\mathrm{Y}-\mathrm{Y}$ recorder where the $X$ axis was a time base and the $\mathrm{Y}$ axes indicated the electrical output in millivolts. With a standard reference junction of $32^{\circ} \mathrm{F}$, the millivolt readings could be converted to an equivalent temperature using standard tables. The area reduction and extrusion speed duplicated those conditions used for the earlier extrusion tests. Once the thermocouples had exited from the die and both

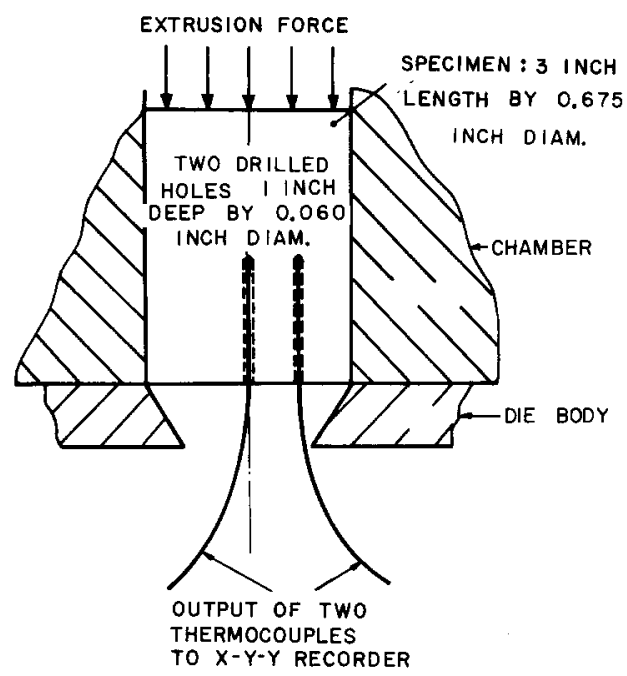

Fig. 3. Schematic illustration showing the initial location of two thermocouples for measuring temperature changes during extrusion of the test polymers.

temperature indications dropped well below the observed maximum, the test was ended. A schematic representation is given in Fig. 3.

\section{EXPERIMENTAL RESULTS}

\section{A. Tensile tests}

All comments here are primarily directed to tensile behavior parallel to the rod axes. Figures 4-6 plus the upper entries of Table 1 include all pertinent results. The three Figures are true stress-strain plots (note the different strain scale in Fig. 6) and it can be observed that the influence of drawing or extruding is to strengthen the polymers in regard to resisting tensile deformations. Polycarbonate and Nylon show quite substantial changes when compared with the behavior of the original material while the changes in polyethylene are more modest for the degree of cold working (area reduction) used in this study. The tensile strengih, which is a measure of maximum load carrying capacity, is relatively unchanged for PE whereas this property is definitely increased for the other polymers (see Table 1).

The true strain at maximum load, which is a measure of the extent of uniform deformation, is increased if these polymers are drawn or extruded. One minor exception to this comment relates to the behavior of drawn Nylon as shown in Table 1. This general observation may be of importance where one anticipates deep drawing such materials; 


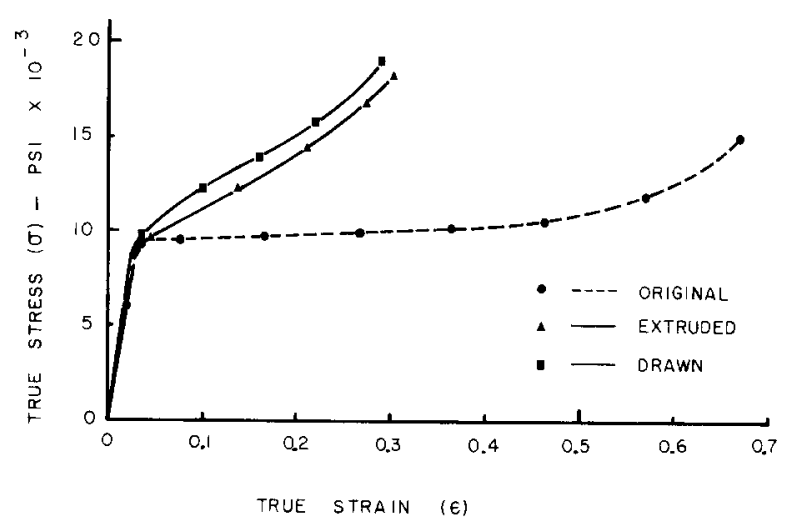

Fig. 4. Tensile true stress--true strain behavior of polycarbonate in the original, drawn and extruded conditions. (Note that all tests were carried to fracture.)

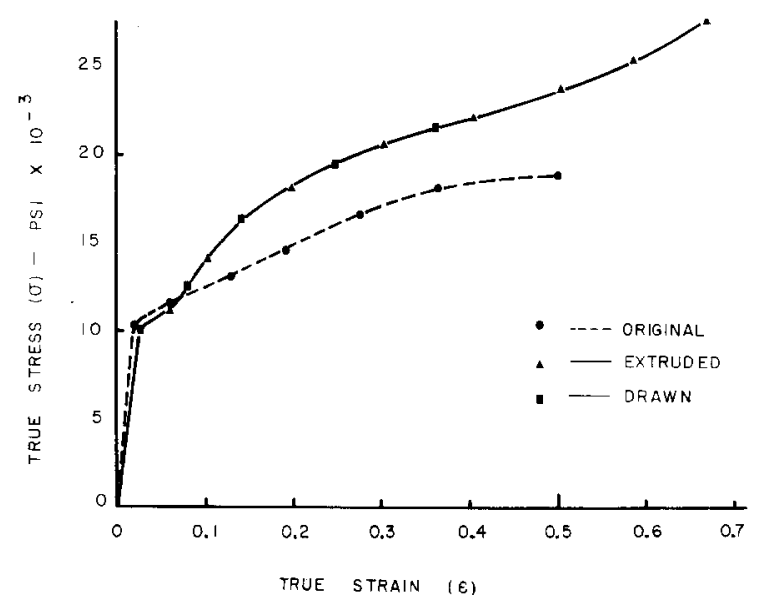

Fig. 5. Tensile true stress-true strain behavior of Nylon in the original, drawn and extruded conditions. (Note that all tests were carried to fracture.)

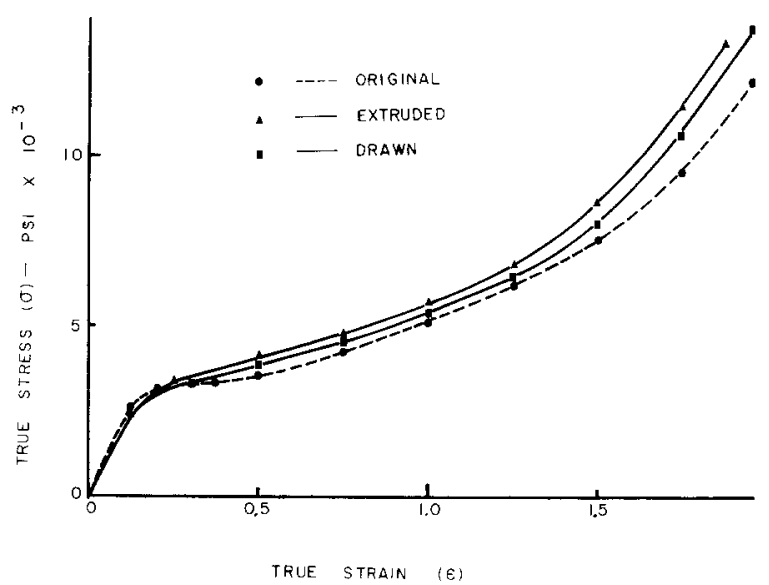

Fig. 6. Tensile true stress-true strain behavior of polyethylene in the original, drawn and extruded conditions. (Note that these tests were not carried to fracture.)

there the delaying of tensile instability (or necking) would permit deeper draws to be accomplished.

Within the limits of the present findings no general comment would accurately describe the influence of these processes on the subsequent true strain at fracture. This, in essence, is one parameter that relates to "ductility." Perhaps of some interest is the behavior of PC after the degree of cold working imparted by either process. Note that this polymer fractures at the maximum load condition, thus, the usual neck formation and propagation did not occur. With all PE specimens, the limit of machine crosshead travel was insufficient to cause fracture; however, the tremendous amount of true strain that this polymer can withstand should be noted.

Regarding the elastic modulus, only the poly-

TABLE 1

Mechanical properties of the three polymers

\begin{tabular}{|c|c|c|c|c|c|c|c|c|c|}
\hline \multirow[t]{2}{*}{ Property } & \multicolumn{3}{|c|}{ Polycarbonate } & \multicolumn{3}{|c|}{ Nylon 6-6 } & \multicolumn{2}{|c|}{ Polyethylene } & \multirow[b]{2}{*}{$D$} \\
\hline & $\star ⿱ O N O$ & $E$ & $D$ & $O$ & $E$ & $D$ & $O$ & $E$ & \\
\hline \multicolumn{10}{|l|}{ Tension: } \\
\hline Elastic modulus-p.s.i. $\times 10^{-3}$ & 330 & 477 & 477 & 490 & 440 & 456 & 126 & 92 & 100 \\
\hline Tensile strength - p.s.i. $\times 10^{-3}$ & 9.22 & 13.35 & 14.20 & 11.90 & 15.35 & 15.40 & 2.74 & 2.65 & 2.50 \\
\hline True strain at maximum load & 0.042 & 0.300 & 0.290 & 0.200 & 0.258 & 0.190 & 0.157 & 0.261 & 0.254 \\
\hline True strain at fracture & 0.670 & 0.300 & 0.290 & 0.500 & 0.744 & 0.358 & $2.11^{+}$ & $+1.87^{+}$ & $1.96^{+}$ \\
\hline \multicolumn{10}{|l|}{ Compression: } \\
\hline Elastic modulus-p.s.i. $\times 10^{-3}$ & 320 & 416 & 394 & 462 & 402 & 385 & 117 & 83 & 95 \\
\hline
\end{tabular}




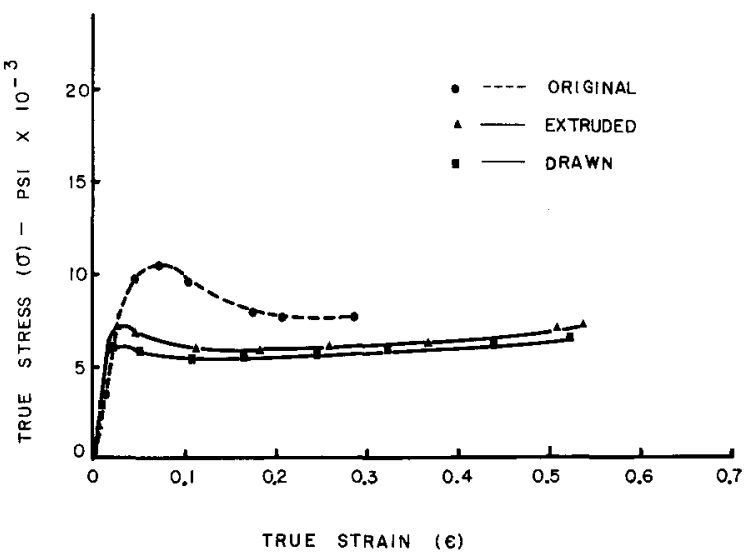

Fig. 7. Compressive true stress-true strain behavior of polycarbonate in the three structural conditions. (Note that these tests were not carried to fracture.)

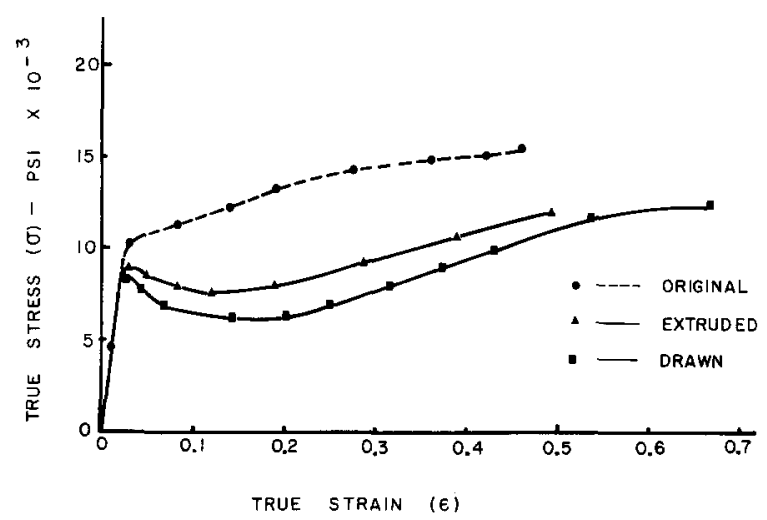

Fig. 8. Compressive true stress-true strain behavior of Nylon in the three structural conditions. (Note that these tests were not carried to fracture.)

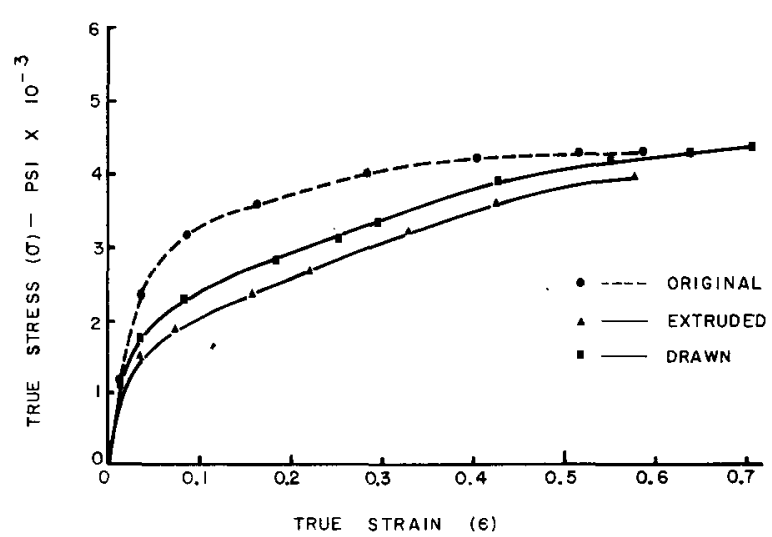

Fig. 9. Compressive true stress-true strain behavior of polyethylene in the three structural conditions. (Note that these tests were not carried to fracture.) carbonate shows an increase due to "cold working"; for the other two, our findings are in general agreement with those published elsewhere 5 .

Because of the uncertainties and variations currently connected with the definition and measurement of "yielding" of polymers, it was decided to forego the inclusion of various "yield strengths" in Table 1.

\section{B. Compression tests}

Figures $7-9$, plus the lower entry in Table 1, contain the pertinent findings when these polymers are subjected to the type of loading shown for $B$ specimens in Fig. 2. Whereas both forming processes tended to strengthen these polymers in terms of subsequent tensile deformation, the exact opposite is seen in compressive loading. Again, these are true stress-true strain curves where the maximum strain value indicated per individual plot was dictated by the onset of non-uniform deformation and not fracture.

The elastic modulus of PC again increases with prior cold working whereas Nylon and PE show a decrease. Corrections for machine stiffness were quite significant for these short specimens.

For reasons explained earlier, values of yield in compression are not quoted here; however, it may be seen in Figs. 4-9 that yielding in compression appears to occur at lower stress levels than in tension.

\section{Directional effects}

The pronounced difference observed between the tensile and compressive loading behavior prompted

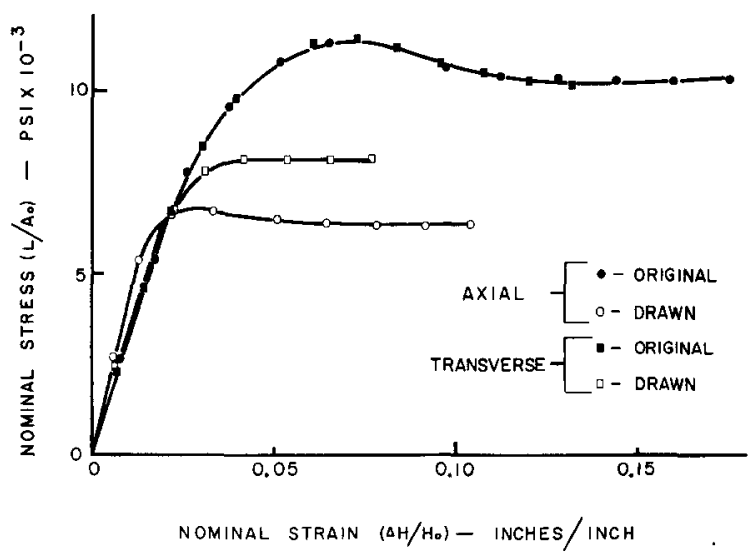

Fig. 10. Comparative compressive behavior of polycarbonate in the original and drawn conditions, as influenced by the direction of loading. 
some further exploratory tests. These were performed with type $\mathrm{C}$ and $\mathrm{D}$ specimens shown in Fig. 2. The only difference between any pair of such specimens was the direction of the applied load. For comparative purposes, a pair of such specimens was made from each polymer in its original condition. Regarding the cold worked condition, PC was tested after drawing while the other two were tested

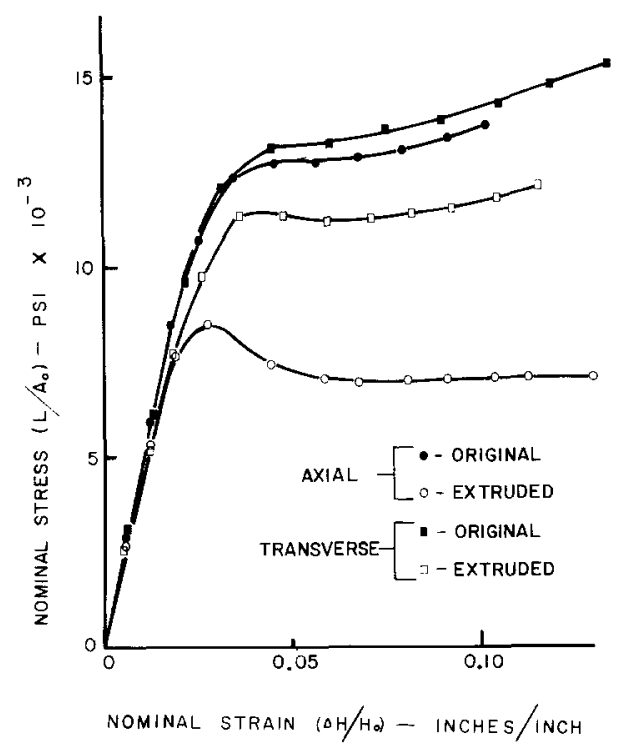

Fig. 11. Comparative compressive behavior of Nylon in the original and extruded conditions, as influenced by the direction of loading. after extrusion. In essence, four tests were performed with each of the three materials. The results are shown in Figs. 10-12 where "axial" refers to a type $\mathrm{D}$ specimen and "transverse" pertains to a type C specimen (see Fig. 2). Although these are nominal or engineering stress-strain plots, they are adequate for indicating several points of interest. First, these results support the findings discussed under Section $\mathrm{B}$ above in that cold forming lowered the compressive resistance to deformation with axial loading. Secondly, any influence of the compressive loading direction with the "original" materials is very slight. Lastly, each cold worked polymer exhibits a decidedly greater resistance to deforma-

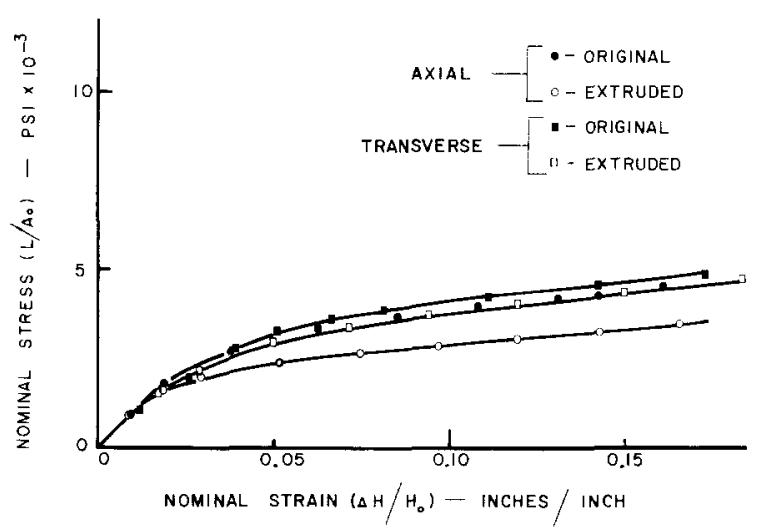

Fig. 12. Comparative compressive behavior of polyethylene in the original and extruded conditions, as influenced by the direction of loading.

TABLE 2

Process and material measurements for the three polymers

\begin{tabular}{|c|c|c|c|}
\hline Description of measured parameter & Polycarbonate & Nylon 6-6 & Polyethylene \\
\hline \multicolumn{4}{|l|}{ Extrusion process: } \\
\hline 1. Maximum pressure-p.s.i. $\times 10^{-3}$ & 10.17 & 11.65 & 4.85 \\
\hline 2. Maximum load in pounds $\times 10^{-3}$ & 3.65 & 4.17 & 1.74 \\
\hline 3. Minimum or steady state pressure-p.s.i. $\times 10^{-3}$ & 6.49 & 10.58 & 3.13 \\
\hline 4. Minimum or steady state load in pounds $\times 10^{-3}$ & 2.32 & 3.78 & 1.12 \\
\hline 5. Nominal per cent reduction of area & 40.5 & 40.5 & 40.5 \\
\hline$\star 6$. Actual per cent reduction of area & 33.8 & 28.6 & 17.3 \\
\hline 7. Maximum temperature rise at center- ${ }^{\circ} \mathrm{F}$ & 20.0 & 16.0 & 3.2 \\
\hline 8. Maximum temperature rise near periphery $-{ }^{\circ} \mathrm{F}$ & 17.0 & 12.0 & 2.0 \\
\hline \multicolumn{4}{|l|}{ Drawing process: } \\
\hline 1. Maximum drawing stress - p.s.i. $\times 10^{-3}$ & 6.13 & 8.20 & 2.17 \\
\hline 2. Maximum load in pounds $\times 10^{-3}$ & 1.33 & 1.78 & 0.47 \\
\hline 3. Minimum or steady state draw stress-p.s.i. $\times 10^{-3}$ & 6.13 & 7.92 & 2.17 \\
\hline 4. Minimum or steady state load in pounds $\times 10^{-3}$ & 1.33 & 1.72 & 0.47 \\
\hline 5. Nominal per cent reduction of area & 40.5 & 40.5 & 40.5 \\
\hline$\star 6$. Actual per cent reduction of area & 37.0 & 32.5 & 18.0 \\
\hline
\end{tabular}

* After recovery for 48 hours. 
tion if loaded across the rod axis rather than parallel to it. In this regard, Nylon shows the greatest difference and PE shows the smallest. There appears to be little question that structure alignment, caused by the forced flow through the die throat, leads to a type of "preferred orientation"; this is a point that warrants further detailed study.

\section{Process variables}

In Table 2 it can be seen that greater loads (in pounds) are required to extrude than to draw. Since other process parameters (speed, die angle, etc.) were equivalent, one must consider the loading mode as a primary cause. Certainly any frictional effects would be more pronounced with extrusion since the initial flow of the billet fills the chamber. Relatively high normal pressures thus develop at the billet-chamber interface with the consequence that frictional resistance contributes to the total resistance that must be overcome by the applied extrusion force. Drawing causes no significant normal pressure between the workpiece and chamber; in fact, the chamber merely acts as a "guide" to prevent any lateral movement of the test section.

There is an added factor that could also lead to the difference in force requirements. It appears ${ }^{7}$ that the yielding of polymers is pressure sensitive and if this is correct, a yield criterion perhaps analogous to the Mohr criterion is useful for these few comments. This type of yield behavior would demand larger applied stresses to cause yielding as the stress state becomes more compressive. As extrusion is "more"compressive than is drawing, the larger observed extrusion load does correlate with pressure sensitive yielding.

When comparing extrusion "pressure" with drawing "stress" it should be realized that the appropriate areas, which are used to convert load to stress or pressure, are different. The area of the chamber is used to determine extrusion pressure while the outlet area of the die enters into drawing stress calculations. Since this latter area is always the smaller of the two, the difference between drawing stress and extrusion pressure will be less than that related to forces. Table 2 contains numerical values that verify these comments.

\section{E. Temperature rise and dimensional recovery}

In Table 2 are listed the values of measured temperature rise when the three polymers were extruded. The maximum value was $20 \mathrm{deg} F$; this occurred along the centerline of the polycarbonate specimen. It does seem that for the two polymers whose $T_{\mathrm{g}}$ is above "room" temperature (i.e. Nylon about $50^{\circ} \mathrm{C}$ and $\mathrm{PC}$ about $150^{\circ} \mathrm{C}$ ), the temperature rise in these studies was of insufficient magnitude to reach these two glass transition temperatures.

As to dimensional recovery (increase in diameter) of these polymers, in each instance the amount of recovery was greater for the extruded than for the drawn rod. This results in a smaller "actual" reduction of area for extrusion and numerical values are listed in Table 2. The larger working loads in extrusion are a probable cause of this greater recovery. For the three polymers, polycarbonate underwent the smallest recovery (i.e. maintained a greater amount of "permanent" deformation) while polyethylene exhibited the most recovery. This behavior shows a direct correlation with the $T_{\mathrm{g}}$ of these materials although this is not meant to imply that the glass transition temperature is the only factor that influences relaxation.

\section{CONCLUSIONS}

1. In a general sense, cold extruding or drawing of polycarbonate, Nylon 6-6, and high density polyethylene tends to raise the tensile true stress-true strain curve and lower the comparable compressive curve.

2. Apparently pronounced directional effects (in regard to resistance to deformation) are introduced when these polymers are drawn or extruded cold.

3. In general, the onset of tensile instability is delayed if these polymers are first cold formed by extruding or drawing.

4. Other factors being equal, extrusion demands greater applied loads than does drawing.

5. Temperature rises during the extruding or drawing of these polymers are quite modest for the combination of conditions used in this study.

6. Other factors being equal, a greater degree of dimensional recovery takes place when these materials are extruded compared with drawing.

\section{ACKNOWLEDGEMENTS}

During this study Mr. Lee received some financial aid through Grant-in-Aids provided by the Union Carbide and Whirlpool Corporations. This assistance is gratefully noted. 


\section{REFERENCES}

1 L. J. Broutman and R. S. Patil, Soc. Plastics Engrs., 28th Ann. Tech. Conf., New York, 1970, p. 20.

2 P. H. Rothschild and B. Maxwell, J. Appl. Polymer Sci., V, 16 (1961) 311 .
3 G. Gruenwald, Mod. Plastics, 38 (1960) 137.

4 L. J. Broutman and S. Kalpakjian, SPE J., 25 (1969) 46.

5 A. Buckley and H. A. Long, Polymer Eng. and Sci., 9 (1969) 664.

6 A. G. Atkins, J. Inst. Metals, 97 (1969) 289.

7 W. Whitney and R. D. Andrews, J. Polymer Sci.. Part C, 16 (1967) 2981.
L'extrusion à froid et l'étirage à froid de tiges en polymères: influence sur le comportement mécanique ultérieur en traction et en compression

Du nylon 6-6, du polycarbonate et du polyéthylène à haute densité ont été extrudés et étirés à travers une embouchure à $40 \%$ de réduction en un seul passage et à température ambiante. Certaines propriétés mécaniques de la tige extrudée ont été mesurées par des essais de traction et de compression. Dans le cas des deux procédés de travail et des trois polymères, en traction, la courbe vrai effortvraie élongation est plus haute par rapport au comportement du matériau à l'état originel tandis qu'en compression, la courbe correspondante est plus basse. On a également trouvé que l'instabilité en traction s'étendait à des déformations plus importantes si ces polymères étaient d'abord travaillés à froid par extrusion ou étirage. Le module d'élasticité de PC accusait une augmentation due à l'extrusion ou à l'étirage, tandis que dans le cas des deux autres polymères, à cause du travail à froid, il décroissait.

En compression, les trois matériaux ont montré des effets directionnels prononcés sous les charges parallèles ou perpendiculaires à l'axe de la tige. Ceci paraît correspondre, qualitativement, à un alignement plus parfait des chaînes dû au passage forcé à travers l'embouchure.

Des mesures exploratoires de température ont indiqué que cette réduction importante de la section ne donne lieu qu'à une élévation de température de $20^{\circ} \mathrm{F}$ au maximum; par ceci, la température de passage à l'état de verre du PC et du nylon n'est pas dépassée.
Strangpressen und Kaltziehen stabförmiger Polymere: Der Einfluß dieser Behandlung auf mechanische Eigenschaften, ermittelt in nachfolgenden Zugund Druckversuchen

Nylon 6-6, Polykarbonat und Polyäthylen hoher Dichte wurden stranggepreßt und bei Raumtemperatur in einem Durchgang durch eine Ziehdüse mit $40 \%$ Reduktion gezogen. Einige mechanische Eigenschaften des gepreßten Materials wurden in nachfolgenden Zug- und Druckversuchen gemessen. Nach beiden Formgebungsprozessen zeigen alle drei Polymere eine höhere Verfestigungskurve als das Ausgangsmaterial bei Zugversuchen und eine niedrigere bei Druckversuchen. Das Einsetzen von Zuginstabilitäten wurde als Folge der Kaltverformung durch Strangpressen oder Ziehen zu größeren Dehnungen hin ausgedehnt. Der Elastizitätsmodul nahm in stranggepreßtem oder gezogenem PC zu; in den beiden anderen Polymeren nahm er jedoch nach Kaltverformung ab.

Stranggepreßte Proben aller drei Materialien zeigten ausgeprägte Richtungseffekte bei Kompression parallel und senkrecht zu ihrer Längsachse. Qualitativ betrachtet spricht das für eine bessere Ausrichtung der Ketten durch das erzwungene Fließen durch die Ziehdüse.

Temperaturmessungen deuten darauf hin, daß bei dieser starken Reduktion des Querschnitts eine maximale Temperaturerhöhung von $20^{\circ} \mathrm{F}$ auftreten kann; durch diese Temperaturerhöhung wird die Glas-Übergangstemperatur von PC und Nylon nicht überschritten. 